\title{
Major range extensions for three species of porcupines (Rodentia: Erethizontidae: Coendou) from the Brazilian Amazon
}

\author{
Fernando Heberson Menezes ${ }^{1,2}{ }^{(D}$, Guilherme Siniciato Terra Garbino ${ }^{3 *}{ }^{\circledR}$, Thiago Borges Fernandes Semedo ${ }^{4}$, \\ Mendelson Lima ${ }^{5}$, Anderson Feijó ${ }^{6}$, Pedro Cordeiro-Estrela ${ }^{2}$ \& Itayguara Ribeiro da Costa \\ ${ }^{1}$ Universidade Federal do Ceará, Programa de Pós-Graduação em Sistemática, Uso e Conservação da \\ Biodiversidade, Centro de Ciências, Fortaleza, CE, Brasil. \\ ${ }^{2}$ Universidade Federal da Paraíba, Laboratório de Mamíferos, Departamento de Sistemática e Ecologia, \\ Centro de Ciências Exatas e da Natureza, João Pessoa, PB, Brasil. \\ ${ }^{3}$ Universidade Federal de Minas Gerais, Instituto de Ciências Biológicas, Programa de Pós-Graduação em \\ Zoologia, Laboratório de Mastozoologia, Campus Pampulha, Belo Horizonte, MG, Brasil. \\ ${ }^{4}$ Museu Paraense Emílio Goeldi (MPEG), Instituto Nacional de Pesquisa do Pantanal (INPP), Programa de \\ Capacitação Institucional, Cuiabá, MT, Brasil. \\ ${ }^{5}$ Universidade do Estado de Mato Grosso, Alta Floresta, MT, Brasil. \\ ${ }^{6}$ Chinese Academy of Sciences, Key Laboratory of Zoological Systematics and Evolution, Institute of Zoology, \\ Beichen West Road, Beijing, China.
}

*Corresponding author: Guilherme Siniciato Terra Garbino,e-mail: gstgarbino@hotmail.com

MENEZES, F. H., GARBINO, G. S. T., SEMEDO, T. B. F., LIMA, M., FEIJÓ, A., CORDEIRO-ESTRELA, P., DA COSTA, I. R. Major range extensions for three species of porcupines (Rodentia: Erethizontidae: Coendou) from the Brazilian Amazon. Biota Neotropica 20(2): e20201030. https:// doi.org/10.1590/1676-0611-BN-2020-1030

Abstract: We report range extensions for three species of Amazonian erethizontids, Coendou bicolor, C. ichillus, and $C$. nycthemera. We record C. ichillus for the first time in Brazil, from Rio Japurá, state of Amazonas. We record $C$. bicolor for the first time in the state of Amazonas, which represents a range extension of approximately $905 \mathrm{~km}$. We also extend the occurrence of C. nycthemera $620 \mathrm{~km}$ to the south into Mato Grosso state. All records are based on museum specimens, highlighting the importance of scientific collections as biodiversity databases and emphasizing the lack of research on Amazonian porcupines.

Keywords: Coendou bicolor, Coendou ichillus, Coendou nycthemera, museum specimens, new record.

\section{Extensão de distribuição de três espécies de porcos-espinhos, gênero Coendou (Rodentia: Erethizontidae) da Amazônia brasileira.}

Resumo: Aqui nós relatamos ampliação de distribuição de três espécies de eretizontídeos amazônicos: Coendou bicolor, C. ichillus e C. nycthemera. Nós registramos pela primeira vez C. ichillus no Brasil, no Rio Japurá, estado do Amazonas. Registramos C. bicolor pela primeira vez no estado Amazonas, o que representa uma ampliação de distribuição de aproximadamente $905 \mathrm{~km}$. Também estendemos a ocorrência de $C$. nycthemera $620 \mathrm{~km}$ ao sul, no estado de Mato Grosso. Todos os registros são baseados em espécimes de museu, enfatizando a importância das coleções científicas como bancos de dados da biodiversidade e a destacando ausência de pesquisas para porcosespinhos amazônicos.

Palavras-chave: Coendou bicolor, Coendou ichillus, Coendou nycthemera, espécime de museu, novo registro. 


\section{Introduction}

New World porcupines (family Erethizontidae) are nocturnal and arboreal rodents with prehensile tails and with hairs modified into sharped quills (Emmons 1997). Erethizontids are distributed from Canada to Uruguay and Argentina (Emmons 1997, Voss 2015). There are 17 species recognized in the family Erethizontidae of which 15 belong to the genus Coendou Lacépède, 1799 (Voss 2015, Feijó \& Langguth 2013, Mendes Pontes et al. 2013). Brazil is the country with the highest diversity of erethizontids, which includes the Atlantic forest endemic, Chaetomys subspinosus, together with nine species of Coendou, of which five are endemic to the country: $C$. nycthemera, $C$ insidiosus, C. roosmalenorum, C. baturitensis and C. speratus (Feijó \& Langguth 2013, Voss 2015, Mendes Pontes et al. 2013, de Freitas et al. 2013).

As cryptic animals, rarely observed in the wild and underrepresented in collections, there are several gaps in the knowledge about the distribution of most porcupine species (Leite et al. 2011, Voss et al. 2013, Feijó \& Langguth 2013, Mendes Pontes et al. 2013). The records for many species are limited to a small number of specimens (e.g. Coendou melanurus as pointed by Voss et al. 2001) or biased towards the surroundings of urban centres and river margins (see maps 405-417 in Voss 2015). Several new distributional records of porcupine species were made recently: Coendou bicolor had new records from Brazil (de Freitas et al. 2013) and a possible record for Colombia (RamírezChaves et al. 2016), Coendou speratus had a distributional gap filled in northeastern Brazil (Nascimento \& dos Santos 2014), Coendou ichillus had new records from Peru (Gregory et al. 2015) and Colombia (Ramírez-Chaves et al.2016), and Coendou rufescens had new records for Ecuador (Narváez-Romero et al. 2018).

In this report, we present new geographical records and updated distribution maps of three species of Amazonian Coendou, with the first records of $C$. ichillus for Brazil and major range extensions of $C$. bicolor and $C$. nycthemera.

\section{Material and Methods}

Specimens (skin, crania, and partial skeletons) of erethizontids were examined in the scientific collections of the American Museum of Natural History (AMNH) in New York, USA; Universidade do Estado de Mato Grosso, campus Alta Floresta (CZAF) in Alta Floresta, Brazil; the Field Museum of Natural History (FMNH) in Chicago, USA; Universidade Federal da Paraíba (UFPB) in João Pessoa, Brazil; Museu Nacional (MNRJ) in Rio de Janeiro, Brazil; Museu Paraense Emílio Goeldi (MPEG) in Belém, Brazil; Museu de Zoologia da Universidade de São Paulo (MZUSP) in São Paulo, Brazil; Universidade de Brasília (UnB) in Brasília, Brazil.

A total of 130 porcupine specimens representing species that occur in the Amazonia were examined (Appendix 1), including the types of $C$. baturitensis, C. ichillus, and C. prehensilis. Taxonomic determination was based on published studies (Feijó \& Langguth 2013, Handley \& Pine 1992, Voss \& Angermann 1997, Voss \& da Silva 2001, Voss et al. 2001, Voss 2011, 2015). The external measurements are the length of head-and-body (HBL) and length of tail (LT) following the protocol in Voss \& Angermann (1997). External measurements were extracted from specimen labels. We estimated the area (in $\mathrm{km}^{2}$ ) of species distribution range based on the minimum convex polygon using ArcMap software version 10.2 .

\section{Results}

Figure 1 shows the updated distribution map of Coendou bicolor, C. ichillus, and C. nycthemera, and Table 1 has the detailed localities. We did not map the record of "Coendou cf. bicolor" for Boyacá, Colombia (Ramírez-Chaves et al. 2016) because it is based on a cranium without an associated skin, and the authors $\operatorname{did}$ not consider $C$. bicolor distinguishable from $C$. prehensilis by cranial characters alone.

The new records of Coendou nycthemera are based on three specimens (CZAF-MA 9, 10, 11, stuffed skins without associated skulls - Figure $2 \mathrm{~b}$ ), an adult male and a female from the right bank of the Rio Teles Pires, and a juvenile (sex undetermined) from the opposite bank of the same river (Table 1). All three records were made in the vicinity of a hydroelectric power plant, the Usina Hidrelétrica Teles Pires, Mato Grosso state, and were previously identified as "Coendou melanurus". Brandão et al. (2019) identified one of these CZAF specimens as "Coendou cf. nycthemera", but those authors could not confirm the identity of the specimen. These new records extend the known geographic range of $C$. nycthemera approximately 620 $\mathrm{km}$ from the closest locality to the northwest (Igarapé Auará, on the left bank of Rio Madeira) and $950 \mathrm{~km}$ from the closest locality to the northeast (Capitariquará, on Rio Tocantins), representing a southward area extension of about $41 \%$ (Figure 1).

Coendou nycthemera can be externally diagnosed from its congeners by its size, length of soft hairs relative to quills, and color pattern of dorsal quills (Table 2). Coendou nycthemera is slightly smaller than C. melanurus and significantly smaller than C. baturitensis and the Amazonian populations referred to C. prehensilis (Table 2). The distal band of the tricolored quills of $C$. nycthemera is very short, inconspicuous or absent, and its colour may be whitish, yellowish or orangish (Figure 3d). Furthermore, Coendou nycthemera differs from the similar-sized C. melanurus and Coendou roosmalenorum by lacking a long, soft fur covering its quills (Voss \& Angermann 1997, Handley \& Pine 1992). The distal band of the guard hairs of C. melanurus are always long and pale yellowish (Voss et al. 2001). Coendou nycthemera has only bicolored quills on its rump whereas $C$. baturitensis and Amazonian $C$. prehensilis have tricolored and bicolored quills on rump. It also differs from C. baturitensis by the dark brownish or black short medial band of the tricolored quills and distal band of bicolored quills (Figure 3). In C. baturitensis the medial band of the tricolored quills and the distal band of the bicolored quills are light brownish (Feijó \& Langguth 2013).

The range extension of Coendou bicolor is based on two specimens previously identified as Coendou prehensilis, a juvenile of unknown sex (MPEG 24574, stuffed skin and skull) and an adult female (MPEG 37122, stuffed skin without associated skull - Figure 2a), both from Estação Ecológica Mamirauá, Uarini, in Amazonas State (Table 1). These records expand the known distribution of C. bicolor approximately $905 \mathrm{~km}$ northeast from Senador Guimard, Acre, Brazil, the closest record in Brazil (de Freitas et al. 2013) and approximately $1,250 \mathrm{~km}$ northeast from Río Alto Ucayali, Ucayali, Peru, the closest record outside Brazil (Voss 2015). The new record comprises an eastward area extension of 53\% (Figure 1). Coendou bicolor is a large porcupine (Table 2) and has no distal bands on its quills (Figure 3c) and no tricolored quill on the rump, differing from the Amazonian $C$. prehensilis and the northeastern Brazil C. baturitensis, both of which have tricolored quills (Figure 3a-b). Coendou bicolor does not have soft fur covering its quills (Voss 2011) differing from C. melanurus 


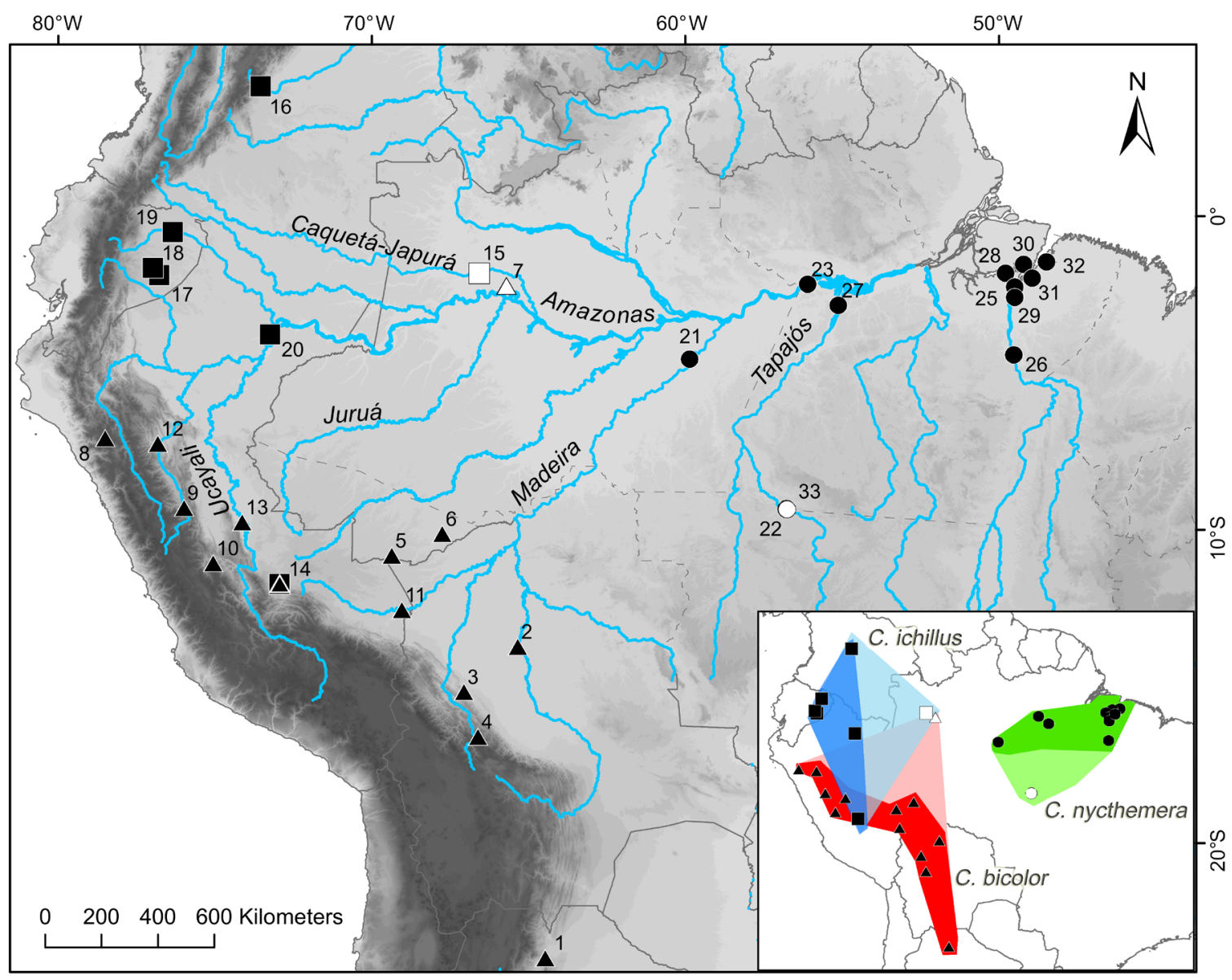

Figure 1. Updated distribution map of Coendou bicolor (triangles), C. ichillus (squares), and C. nycthemera (circles). New records are represented by white symbols. Detailed locality data is in Table 1. Inset map shows the previous distribution (darker shades) and the updated polygon (lighter shades) of C. bicolor (red), C. ichillus (blue), and C. nycthemera (green).

(Voss et al. 2001) and C. roosmalenorum (Voss \& da Silva 2001). We compared specimen MPEG 24574 with juveniles of other species housed in the visited collections. It has dorsal tricolored quills with a very short orangish distal band and a very wider medial blackish band. Its rump and tail lack tricolored quills and have a soft ventral pelage. These characteristics are more similar to the adult MPEG 37122 than to the juveniles of other species.

The record of Coendou ichillus is based on an adult male (MZUSP 11465, Figure 2c), collected on November 21, 1977, on the margins of Rio Japurá, at Limoeiro in Amazonas State (Table 1). The specimen is preserved as an open skin with the cranium and skeleton removed and was previously identified as "Coendou prehensilis" by P.E. Vanzolini. This is the first record of C. ichillus in Brazil and extends its distribution eastwards approximately $790 \mathrm{~km}$ from Iquitos, Peru, the closest known record (Voss \& da Silva 2001), representing an increase of $55 \%$ on its estimated distribution area (Figure 1). The specimen matches the $C$. ichillus description given by Voss \& da Silva (2001) and it is a mediumsized porcupine (Table 2) that differs from the similar C. melanurus and $C$. roosmalenorum by the absence of long hairs covering its quills and from $C$. nycthemera by the presence of tricolored bristle-quills on its dorsum (Voss \& da Silva 2001). It is also distinct from the larger $C$. prehensilis and C. baturitensis by the lack of tricolored quills on the rump and the presence of bristle-like quills on the dorsum (Figure $3 \mathrm{~g}$ ).

\section{Discussion}

Natural history information on Coendou species is scant in the literature, especially for the Amazonian taxa (Voss, 2015). Even their distribution ranges are poorly defined. For example, Voss (2015) considered $C$. nycthemera associated with the lower Amazonas, Madeira, and Tocantins rivers. With the new record presented here, we demonstrate that $C$. nycthemera occurs further south, along the banks of the Rio Teles Pires in Mato Grosso (Figure 1). Considering the new potential distribution of C. nycthemera, it is plausible that it also occurs in the Amazon of the state of Maranhão, as suggested by de Oliveira et al. (2007), and in the northern tip of the state of Tocantins.

Coendou bicolor was previously thought to occur exclusively along the Andean foothills and in adjacent lowland forest (Voss, 2015), our record from the Brazilian state of Amazonas expands its potential distribution area in about 53\% towards central Amazon. Similarly, C. ichillus had a restricted distribution limited to east Ecuador, north Peru, and Colombia, and the record from Rio Japurá increases by $55 \%$ its potential range (Figure 1). Altogether, our findings contribute 
Menezes FH, et al.

Table 1. Locality records of Coendou bicolor, C. ichillus, and C. nycthemera. Localities are ordered by species, country, state/department, and locality, and the \#ID refers to map in Figure 1.

\begin{tabular}{|c|c|c|c|c|c|c|}
\hline \#ID & Species & Country & $\begin{array}{c}\text { Department// } \\
\text { State/Province }\end{array}$ & Locality & Coordinates & Source \\
\hline 1 & C. bicolor & Argentina & Jujuy & Yuto & $23^{\circ} 39^{\prime} \mathrm{S} 64^{\circ} 28^{\prime} \mathrm{W}$ & Lucero (1987) \\
\hline 3 & C. bicolor & Bolivia & Beni & Yucumo & $15^{\circ} 10^{\prime} \mathrm{S} 67^{\circ} 04^{\prime} \mathrm{W}$ & Voss (2015) \\
\hline 4 & C. bicolor & Bolivia & Cochabamba & Charuplaya & $16^{\circ} 36^{\prime} \mathrm{S} 66^{\circ} 37^{\prime} \mathrm{W}$ & Voss (2015) \\
\hline 6 & C. bicolor & Brazil & Acre & Senador Guimard, on AC-040 road & $10^{\circ} 07^{\prime} 12^{\prime \prime} \mathrm{S} 67^{\circ} 45^{\prime} 15^{\prime \prime} \mathrm{W}$ & Freitas et al. (2013) \\
\hline 7 & C. bicolor & Brazil & Amazonas & $\begin{array}{l}\text { Reserva de Desenvolvimento } \\
\text { Sustentável Mamirauá }\end{array}$ & $2^{\circ} 12^{\prime} 54.43^{\prime} \mathrm{S} 65^{\circ} 42^{\prime} 35.53^{\prime \prime} \mathrm{W}$ & MPEG 24574, 37122 \\
\hline 8 & C. bicolor & Peru & Cajamarca & $2.5 \mathrm{~km} \mathrm{~N}$ of Monte Seco & $7^{\circ} 03^{\prime} 51.32^{\prime} \mathrm{S}$ 78³0’25.80’'W & Voss (2015) \\
\hline 9 & C. bicolor & Peru & Huánuco & Tingo María & $9^{\circ} 17^{\prime} 38.07^{\prime \prime S} 75^{\circ} 59^{\prime} 39.02^{\prime \prime} \mathrm{W}$ & Voss (2015) \\
\hline 12 & C. bicolor & Peru & San Martín & $\begin{array}{c}\text { Área de Conservación Municipal } \\
\text { Mishquiyacu-Rumiyacu y Almendra }\end{array}$ & $7^{\circ} 14^{\prime} 40.16^{\prime} \mathrm{S}$ 7649’33.47’'W & Voss (2015) \\
\hline 13 & C. bicolor & Peru & Ucayali & Río Alto Ucayali & $9^{\circ} 45^{\prime} 00^{\prime \prime S} 74^{\circ} 07^{\prime} 59.99^{\prime \prime} \mathrm{W}$ & Voss (2015) \\
\hline 14 & $\begin{array}{l}\text { C. bicolor and } \\
\text { C. ichillus }\end{array}$ & Peru & Cusco & $\begin{array}{c}\text { Confluence of Ríos Camisea and } \\
\text { Urubamba }\end{array}$ & $\begin{array}{l}11^{\circ} 43^{\prime} 16.80 " \mathrm{~S} \\
72^{\circ} 56^{\prime} 31.20^{\prime \prime} \mathrm{W}\end{array}$ & Gregory et al. (2015) \\
\hline 15 & C. ichillus & Brazil & Amazonas & Limoeiro, Japurá, Rio Japurá & $1^{\circ} 49^{\prime} \mathrm{S} 66^{\circ} 35^{\prime} \mathrm{W}$ & MZUSP 11465 \\
\hline 16 & C. ichillus & Colombia & Meta & $\begin{array}{c}\text { Villavicencio, } \mathrm{km} 30 \text { carretera a } \\
\text { Caños Negros }\end{array}$ & $4^{\circ} 09^{\prime} 25^{\prime \prime \prime} \mathrm{N} 73^{\circ} 33^{\prime} 21^{\prime \prime} \mathrm{W}$ & $\begin{array}{l}\text { Ramírez-Chaves et al. } \\
\text { (2016) }\end{array}$ \\
\hline 17 & C. ichillus & Ecuador & Pastaza & Río Conambo & $1^{\circ} 52^{\prime} \mathrm{S} 76^{\circ} 46^{\prime} 60^{\prime \prime} \mathrm{W}$ & Voss and da Silva (2001) \\
\hline 23 & C. nycthemera & Brazil & Pará & ALCOA harbor, Juruti & $2^{\circ} 10^{\prime} \mathrm{S} 56^{\circ} 06^{\prime} \mathrm{W}$ & MPEG 38377 \\
\hline 24 & C. nycthemera & Brazil & Pará & Belém & $1^{\circ} 27^{\prime} \mathrm{S} 48^{\circ} 29^{\prime} \mathrm{W}$ & Voss (2015) \\
\hline 25 & C. nycthemera & Brazil & Pará & Cametá & $2^{\circ} 15^{\prime} \mathrm{S} 49^{\circ} 30^{\prime} \mathrm{W}$ & Voss (2015) \\
\hline 26 & C. nycthemera & Brazil & Pará & $\begin{array}{l}\text { Capitariquará, extreme South of Ilha } \\
\text { Tocantins, rio Tocantins, } 78 \mathrm{~km} \mathrm{~S} \text { and } \\
16 \mathrm{~km} \text { E, Tucuruí }\end{array}$ & $4^{\circ} 25^{\prime} \mathrm{S} 49^{\circ} 32^{\prime} \mathrm{W}$ & MPEG 12496 \\
\hline 27 & C. nycthemera & Brazil & Pará & Caxiricatuba & $2^{\circ} 50^{\prime} \mathrm{S} 55^{\circ} 08^{\prime} \mathrm{W}$ & MZUSP 5035 \\
\hline 28 & C. nycthemera & Brazil & Pará & Curralinho, Marajó island & $1^{\circ} 48^{\prime} \mathrm{S} 49^{\circ} 47^{\prime} \mathrm{W}$ & Voss (2015) \\
\hline 29 & C. nycthemera & Brazil & Pará & Mocajuba & $2^{\circ} 34^{\prime} \mathrm{S} 49^{\circ} 30^{\prime} \mathrm{W}$ & Voss (2015) \\
\hline 30 & C. nycthemera & Brazil & Pará & Muaná & $1^{\circ} 31^{\prime} \mathrm{S} 49^{\circ} 13^{\prime} \mathrm{W}$ & Voss (2015) \\
\hline 31 & C. nycthemera & Brazil & Pará & $\begin{array}{c}\text { Rio Meruú, left margin, PA-151, Km } \\
\text { 18. Igarapé-Miri }\end{array}$ & $1^{\circ} 58^{\prime} \mathrm{S} 48^{\circ} 57^{\prime} \mathrm{W}$ & MPEG 24191 \\
\hline 32 & C. nycthemera & Brazil & Pará & $\begin{array}{c}\text { Santa Teresinha, Km 87-94 of the } \\
\text { BR-010 road }\end{array}$ & $1^{\circ} 16^{\prime} \mathrm{S} 48^{\circ} 05^{\prime} \mathrm{W}$ & MZUSP 25591 \\
\hline 33 & C. nycthemera & Brazil & Pará & $\begin{array}{l}\text { Teles Pires Hydroelectric Reservoir, } \\
\text { right bank of Rio Teles Pires }\end{array}$ & $9^{\circ} 20^{\prime} \mathrm{S} 56^{\circ} 46^{\prime} \mathrm{W}$ & $\begin{array}{c}\text { CZAF-MA 9, CZAF-MA } \\
11 .\end{array}$ \\
\hline
\end{tabular}




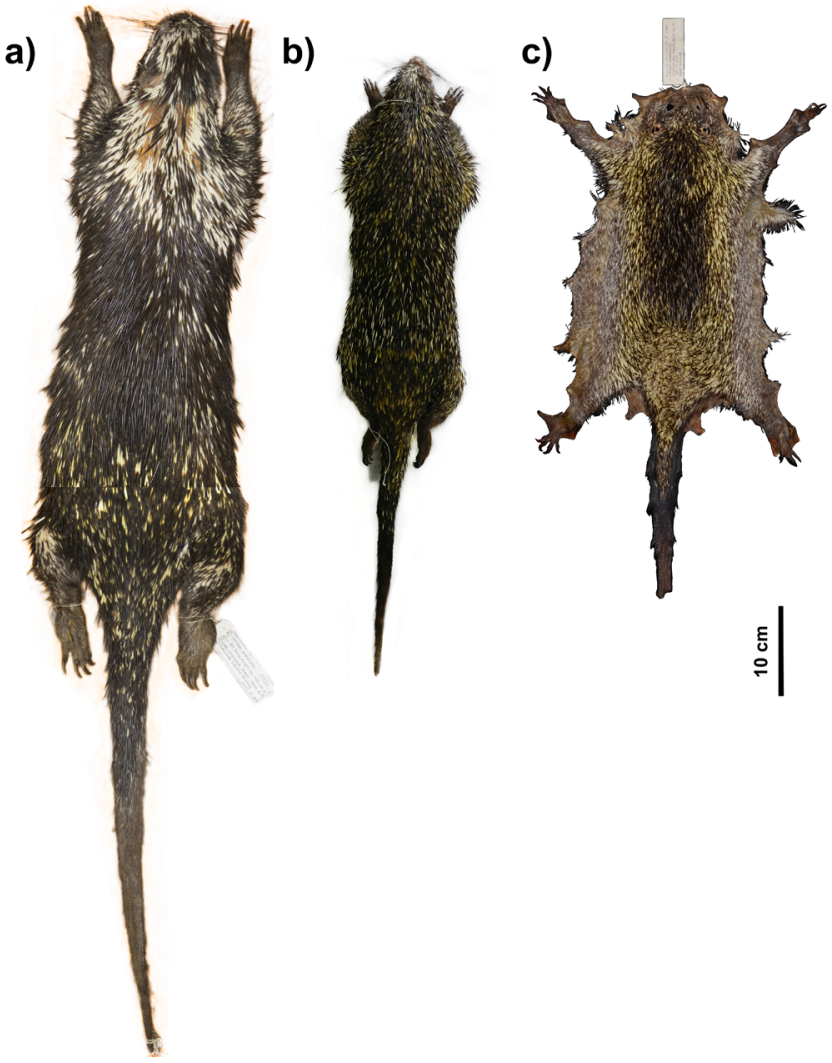

Figure 2. Skins in dorsal view of a) Coendou bicolor (MPEG 37122), b) C. nycthemera (CZAF-MA 10), and c) C. ichillus (MZUSP 11465).

significantly to a better delimitation of the range of these three Amazonian porcupines.

Our study also suggests broader patterns of sympatry among Coendou species. Approximately $100 \mathrm{~km}$ south to the new localities of $C$. nycthemera reported here, we (GSTG and TBFS) observed a larger species of Coendou, here identified as C. prehensilis (ca. $10^{\circ} 20^{\prime} \mathrm{S}$ $56^{\circ} 58^{\prime} \mathrm{W}$ - Figure 4 ), suggesting that these two taxa are sympatric in the region, as has been recorded elsewhere (Handley \& Pine 1992). The new localities for C. bicolor (locality 7 in Figure 1) and C. ichillus (locality 15 in Figure 1) are just $100 \mathrm{~km}$ apart in the north-western region of Amazonas state and support the hypothesis that the two taxa occur in sympatry throughout much of their range, as observed by Gregory et al. (2015), who photographed both species using the same branches of a tree in southwestern Peru.

The three species reported here can be differentiated from their congeners based on external traits, particularly the morphology of the quills, which can be assessed in the field or in museums (Table 2, Figure 3). Nevertheless, cranial characters and molecular sequence data are important to provide unequivocal identification of some taxa. It is noteworthy that all the new records presented here are based on misidentified museum specimens. Some individuals, as the $C$. ichillus from MZUSP, were collected about 40 years ago. These results highlight both the importance of scientific collections in preserving a still unknown biodiversity and how poor is our current knowledge about the taxonomy and distribution of Neotropical porcupines.
From a conservation viewpoint, the areas where Coendou nycthemera was recorded, in southern (localities 22,33 in Figure 1) and eastern Amazonia (localities 25, 26, and 28-32, in Figure 1) are under intense pressure from cattle ranching, agricultural developments, and selective logging (Gascon et al. 2001, Yoshikawa \& Sanga-Ngoie 2011, Silva \& Lima 2018). Therefore, our new record documents an arboreal mammal that is likely being affected by intense deforestation in the southern Amazon of Mato Grosso, in the same manner as monkeys such as Mico emiliae, Saguinus niger, and the recently described Callicebus grovesi, all of which occur in the region (Garbino et al. 2015, Boubli et al. 2019).

Our paper provides new data on the geographical distribution of Coendou species, recording for the first time C. ichillus for Brazil and reporting major range extensions for $C$. bicolor and $C$. nycthemera. With the new record of $C$. ichillus for Brazil, there are now 10 species of Coendou confirmed in the country (de Freitas et al. 2013, Voss 2015). Considering the most up-to-date catalogue of the Brazilian mammals (Quintela et al. in press), there are now 744 species of mammals in the country.

All records presented herein are based on scientific collections, reinforcing their importance as repositories of still unknown mammalian diversity, even for large species such as erethizontids. We would like to point out that due to the science cuts imposed by the Brazilian federal government (de Oliveira Andrade 2019), it is likely that biodiversity studies based on scientific collections will be severely impacted.

\section{Supplementary material}

The following online material is available for this article: Appendix 1

\section{Acknowledgements}

We are grateful to the curators and staff of the visited collections for allowing us to examine specimens under their care, and to Diego Astua, Robert Voss and two anonymous referees, whose suggestions were most constructive. Thank you also to Alexandra Bezerra and Fabio Nascimento for sending photographs of museum specimens. TSBF is supported by the Conselho Nacional de Desenvolvimento Científico e Tecnológico ( $\mathrm{CNPq}$ ) and the Ministério da Ciência, Tecnologia, Inovações e Comunicações (MCTIC) through the scholarship (process 300617/2020-8). FHM and GSTG receive predoctoral fellowships from Coordenação de Aperfeiçoamento de Pessoal de Nível Superior (CAPES) of Ministério da Educação (MEC).

\section{Author Contributions}

Fernando Heberson Menezes - Substantial contribution in the concept and design of the study, Contribution to data collection, Contribution to data analysis and interpretation, Contribution to manuscript preparation.

Guilherme Siniciato Terra Garbino - Substantial contribution in the concept and design of the study, Contribution to data collection, Contribution to data analysis and interpretation, Contribution to manuscript preparation. 
Menezes FH, et al.

Table 2. External diagnostic characters of the Brazilian Amazonian porcupines. See Materials and Methods for measure abbreviations.

\begin{tabular}{|c|c|c|c|c|}
\hline & Size & Soft hair & $\begin{array}{l}\text { Long dorsal quills/bristle- } \\
\text { quills/guard hairs }\end{array}$ & Short dorsal quills \\
\hline C. nycthemera & $\begin{array}{c}\text { Small } \\
\text { (HBL: } 344 \pm 22 \mathrm{~mm} ; \mathrm{LT}: \\
313 \pm 25 \mathrm{~mm}) \\
\text { (Voss \& Angermann } \\
1997)\end{array}$ & Does not cover the quills & $\begin{array}{l}\text { Tricolored or bicolored. } \\
\text { Basal band short and } \\
\text { yellowish, medial band } \\
\text { blackish and long. Distal } \\
\text { band, when present, very } \\
\text { short. May be whitish, } \\
\text { yellowish or orangish }\end{array}$ & $\begin{array}{l}\text { Bicolored. Short basal } \\
\text { band yellowish and long } \\
\text { distal band blackish }\end{array}$ \\
\hline & Large & & Bicolored. & Bicolored. \\
\hline C. bicolor & $\begin{array}{l}\text { (Mean HBL: } 457 \mathrm{~mm} \text {; } \\
\text { Mean LT: } 422 \mathrm{~mm} \text { ) } \\
\text { (Voss 2011) }\end{array}$ & Does not cover the quills & $\begin{array}{l}\text { Short basal band slightly } \\
\text { yellowish; long distal } \\
\text { band blackish }\end{array}$ & $\begin{array}{l}\text { Short basal band yel- } \\
\text { lowish; long distal band } \\
\text { blackish }\end{array}$ \\
\hline Amazonian C. prehensilis & $\begin{array}{c}\text { Large } \\
\text { (HBL: } 451 \pm 25 \mathrm{~mm} ; \mathrm{LT}: \\
453 \pm 31 \mathrm{~mm} \\
\text { (Voss 2011) }\end{array}$ & Does not cover the quills & $\begin{array}{l}\text { Bicolored and tricolored. } \\
\text { Tricolored quills have } \\
\text { basal band slightly yel- } \\
\text { lowish, long blackish } \\
\text { medial band and short } \\
\text { whitish distal band. Bicol- } \\
\text { ored quills have slightly } \\
\text { yellowish basal band and } \\
\text { the blackish distal band }\end{array}$ & $\begin{array}{l}\text { Bicolored and tricolored. } \\
\text { Tricolored quills have } \\
\text { basal band yellowish, } \\
\text { long blackish medial band } \\
\text { and short whitish distal } \\
\text { band. Bicolored quills } \\
\text { have yellowish basal band } \\
\text { and the blackish distal } \\
\text { band }\end{array}$ \\
\hline C. baturitensis & $\begin{array}{c}\text { Large } \\
\text { (HBL: 500mm; LT: } \\
\text { 460mm) } \\
\text { (Feijó \& Langguth 2013) }\end{array}$ & Does not cover the quills & $\begin{array}{l}\text { Bicolored and tricolored. } \\
\text { Tricolored quills have } \\
\text { whitish basal band, long } \\
\text { brownish medial band and } \\
\text { short whitish distal band. } \\
\text { Bicolored quills have } \\
\text { short whitish basal band } \\
\text { and long brownish distal } \\
\text { band }\end{array}$ & $\begin{array}{l}\text { Bicolored and tricolored. } \\
\text { Tricolored quills have } \\
\text { whitish basal band, long } \\
\text { brownish medial band and } \\
\text { short whitish distal band. } \\
\text { Bicolored quills have } \\
\text { short whitish basal band } \\
\text { and long brownish distal } \\
\text { band }\end{array}$ \\
\hline
\end{tabular}

* based on measurements of the examined specimens.

Thiago Borges Fernandes Semedo - Substantial contribution in the concept and design of the study, Contribution to data collection, Contribution to data analysis and interpretation, Contribution to manuscript preparation.
Mendelson Lima - Contribution to data collection, Contribution to critical revision, adding intelectual content.

Anderson Feijó - Substantial contribution in the concept and design of the study, Contribution to data collection, Contribution to data analysis and interpretation, Contribution to manuscript preparation. 


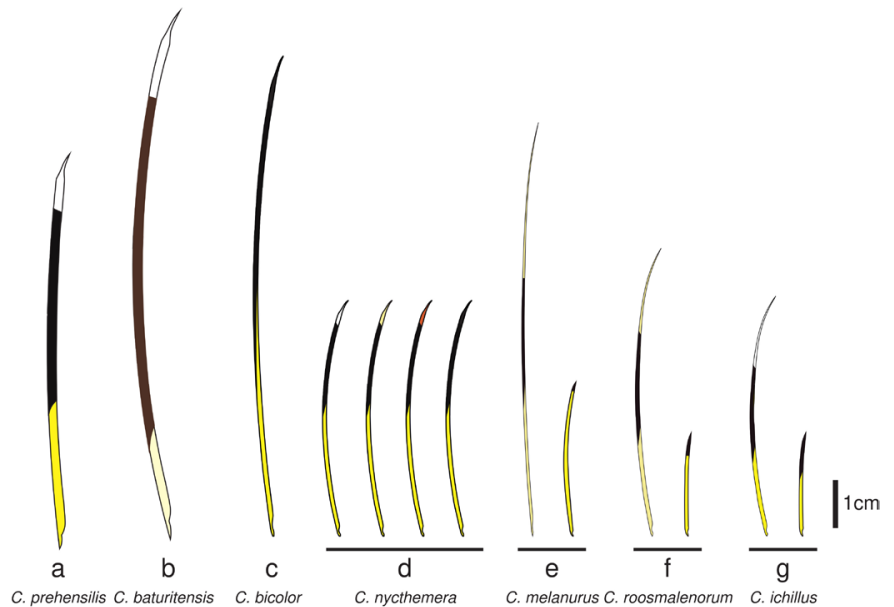

Figure 3. Quills and bristle-quills of selected species of Brazilian porcupines. a) Amazonian C. prehensilis long tricolored quill, b) C. baturitensis long tricolored quill, c) C. bicolor long bicolored quill, d) C. nycthemera long quills with different distal band colors, e) C. melanurus tricolored guard hair and bicolored quill, f) C. roosmalenorum tricolored bristle-quill and bicolored quill, and g) $C$. ichillus tricolored bristle-quill and bicolored quill.

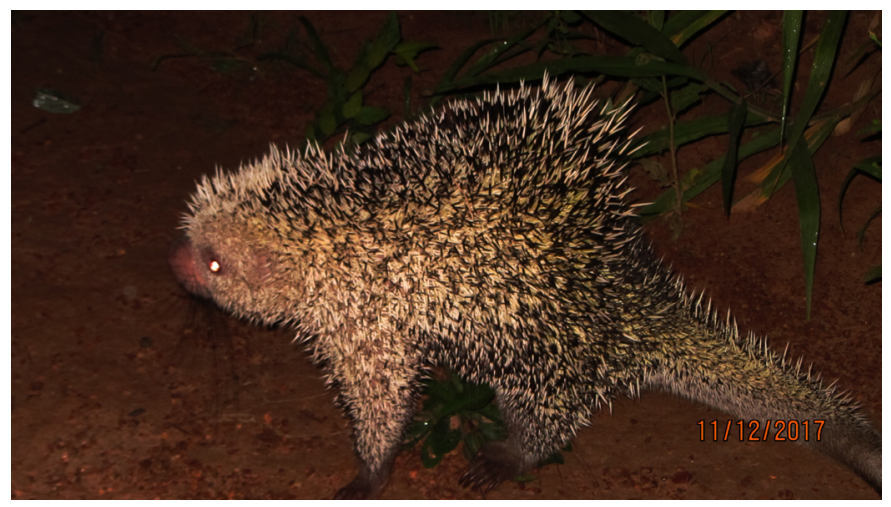

Figure 4. Coendou prehensilis observed close to Nova Monte Verde, Mato Grosso, Brazil.

Pedro Cordeiro-Estrela - Contribution to critical revision, adding intelectual content .

Itayguara Ribeiro da Costa - Contribution to critical revision, adding intelectual content.

\section{Conflicts of Interest}

On behalf of the co-authors, I declare that there is no conflict of interest related to the publication of this manuscript

\section{Ethics}

This study did not involve animal experimentation or collecting, as the analyzed specimens were already deposited in scientific collections.

\section{Data Availability}

Every information necessary to replicate this study is present in the manuscript text

\section{References}

BOUBLI, J.P. et al. 2019. On a new species of titi monkey (Primates: Plecturocebus Byrne et al., 2016), from Alta Floresta, southern Amazon, Brazil. Mol. Phylogenet. Evol. 132(July 2018):117-137.

BRANDÃO, M.V., GARBINO, G.S.T., SEMEDO, T.B.F., FEIJÓ, A., DO NASCIMENTO, F.O., FERNANDES-FERREIRA, H., ROSSI, R.V., DALPONTE, J. \& CARMIGNOTTO, A.P. 2019. Mammals of Mato Grosso, Brazil: Annotated species list and historical review. Mastozoología Neotrop. 26(2):1-44.

EMMONS, L.H. 1997. Neotropical Rainforest Mammals: A field guide. The University of Chicago Press, Chicago.

FEIJÓ, A. \& LANGGUTH, A. 2013. Mamíferos de médio e grande porte do Nordeste do Brasil: Distribuição e taxonomia, com descrição de novas espécies. Rev. Nord. Biol. 22(1):3-225.

DE FREITAS, M.A., DE FRANÇA, D.P.F. \& VERÍSSIMO, D. 2013. First record of the Bicoloured-spined Porcupine Coendou bicolor (Tschudi, 1844) for Brazil. Check List 9(1):94.

GARBINO, G.S.T., SEMEDO, T.B.F. \& PANSONATO, A. 2015. Notes on the western black-handed tamarin, Saguinus niger (É. Geoffroy, 1803) (Primates) from an Amazonia-Cerrado ecotone in central-western Brazil: new data on its southern limits. Mastozoología Neotrop. 22(2):311-318.

GASCON, C., BIERREGAARD JR, R.O., LAURANCE, W.F. \& RANKIN-DEMERONA, J. 2001. Deforestation and forest fragmentation in the Amazon. In Lessons from Amazonia: The ecology and conservation of a fragmented forest (R. O. Bierregaard Jr, C. Gascon, T. E. Lovejoy, \& R. Mesquita, eds) Yale University Press, New Haven, p.22-30.

GREGORY, T., LUNDE, D.P., ZAMORA-MEZA, H.T., CARRASCO-RUEDA, F., ZAMORA MEZA, H.T. \& CARRASCO-RUEDA, F. 2015. Records of Coendou ichillus (Rodentia, Erethizontidae) from the Lower Urubamba Region of Peru. Zookeys 509(June):109-121.

HANDLEY, C.O. \& PINE, R.H. 1992. A new species of prehensile-tailed porcupine, genus Coendou Lacépède, from Brazil. Mammalia 56(2):237244.

LEITE, Y.L.R., CALDARA JR, V., LOSS, A.C., COSTA, L.P., MELO, É.R.A., GADELHA, J.R. \& MENDES PONTES, A.R. 2011. Designation of a neotype for the Brazilian porcupine, Coendou prehensilis (Linnaeus, 1758). Zootaxa 279130-40.

LUCERO, M.M. 1987. Sobre la presencia de dos taxa de Coendou en el Norte Argentino (Mammalia, Erethizontidae). Acta Zool. Lilloana 3937-41.

MENDES PONTES, A.R., GADELHA, J.R., MELO, É.R.A., DE SÁ, F.B., LOSS, A.C., CALDARA JR, V., COSTA, L.P. \& LEITE, Y.L.R. 2013. A new species of porcupine, genus Coendou (Rodentia: Erethizontidae) from the Atlantic forest of northeastern Brazil. Zootaxa 3636(3):421.

NARVÁEZ-ROMERO, C., REYES-PUIG, C., VALLE, D. \& BRITO, J. 2018. New records and estimation of the potential distribution of the stump-tailed porcupine Coendou rufescens. Therya 9(2):137-146.

NASCIMENTO, A.L. da C.P. \& DOS SANTOS, J.W. 2014. Coendou speratus Mendes Pontes, Gadelha, Melo, Sá, Loss, Caldara Jr., Costa \& Leite, 2013 (Mammalia, Rodentia, Erethizontidae) in northeastern Brazil: Filling gaps in its geographical distribution. Check List 10(5):1223-1225.

DE OLIVEIRA ANDRADE, R. 2019. Brazil's budget cuts threaten more than 80,000 science scholarships. Nature 572(7771):575-576.

DE OLIVEIRA, T.G., GERUDE, R.G. \& E SILVA-JÚNIOR, J. de S. 2007. Unexpected mammalian records in the state of Maranhão. Bol. do Mus. Parana. Emílio Goeld 2(2):23-32.

QUINTELA, F.M., ROCA, C.A. \& FEIJÓ, A. Updated and annotated checklist of recent mammals from Brazil. Anais da Academia Brasileira de Cienciências. An. da Acad. Bras. Ciência.

RAMÍREZ-CHAVES, H.E., SUÁREZ-CASTRO, A.F., MORALESMARTÍNEZ, D.M. \& VALLEJO-PAREJA, M.C. 2016. Richness and distribution of porcupines (Erethizontidae: Coendou) from Colombia. Mammalia 80(2):181-191.

SILVA, C.A. \& LIMA, M. 2018. Soy Moratorium in Mato Grosso: Deforestation undermines the agreement. Land use policy 71(November):540-542. 
Menezes FH. et al.

VOSS, R.S. 2011. Revisionary Notes on Neotropical Porcupines (Rodentia: Erethizontidae) 3. An annoted Checklist on the species of Coendou Lacépède, 1799. Am. Museum Novit. (3720):1-36.

VOSS, R.S. 2015. Superfamily Erethizontoidea Bonaparte, 1845. In Mammals of South America, Volume 2: Rodents (J. L. Patton, U. F. J. Pardiñas, \& G. D'Elía, eds) The University of Chicago Press, Chicago, p.786-805.

VOSS, R.S. \& ANGERMANN, R. 1997. Revisionary Notes on Neotropical Porcupines (Rodentia: Erethizontidae). 1. Type material described by Olfers (1818) and Kuhl (1820) in the Berlin Zoological Museum. Am. Museum Novit. (3214):1-44.

VOSS, R.S., HUBBARD, C. \& JANSA, S.A. 2013. Phylogenetic relationships of New World porcupines (Rodentia, Erethizontidae): implications for taxonomy, morphological evolution, and biogeography. Am. Museum Novit. (3769):1-36.
VOSS, R.S., LUNDE, D.P. \& SIMMONS, N.B. 2001. The Mammals of Paracou, French Guiana: a neotropical lowland rainforest fauna Part 2. Nonvolant species. Bull. Am. Museum Nat. Hist. 2631-236.

VOSS, R.S. \& DA SILVA, M.N.F. 2001. Revisionary Notes on Neotropical Porcupines (Rodentia: Erethizontidae). 2 . A review of the Coendou vestitus group with descriptions of two new species from Amazonia. Am. Museum Novit. (3351):1-36.

YOSHIKAWA, S. \& SANGA-NGOIE, K. 2011. Deforestation dynamics in Mato Grosso in the southern Brazilian Amazon using GIS and NOAA/AVHRR data. Int. J. Remote Sens. 32(2):523-544.

Received: $23 / 04 / 2020$

Accepted: 03/05/2020

Published online: 19/06/2020 